\section{Storm in Japan over sale of zoo monkeys for research}

[TOKYO] The Japan Monkey Center, a primate research centre in Inuyama, Aichi Prefecture, has come under attack from animal rights activists for arranging the sales of monkeys obtained from zoological parks to medical research laboratories.

More than 160 Japanese macaques were obtained from zoos across Japan this year to be sold to research institutes for $¥ 75,000$ (US\$540) each.

Animal rights groups, such as All Life in a Viable Environment (ALIVE), last week criticized the centre's role as unethical, saying that zoo animals should not be sold, let alone be "savaged" in animal experiments.

But the monkey centre is defending its position, saying that the macaques were obtained from zoos suffering from an overpopulation of the animal, and that experiments using primates are crucial for the advance of medical sciences.

The shortage of research monkeys is a serious concern for biomedical researchers in Japan. Demand for the animals is rising with advances in brain sciences and research on HIV vaccines and gene therapy, and many scientists say that the high cost and shortage of supply is starting to affect their work.

Last year, the Japan Neuroscience Society submitted a report to the Ministry of Education, Science, Sports and Culture, raising problems generated by the lack of research monkeys in Japan.

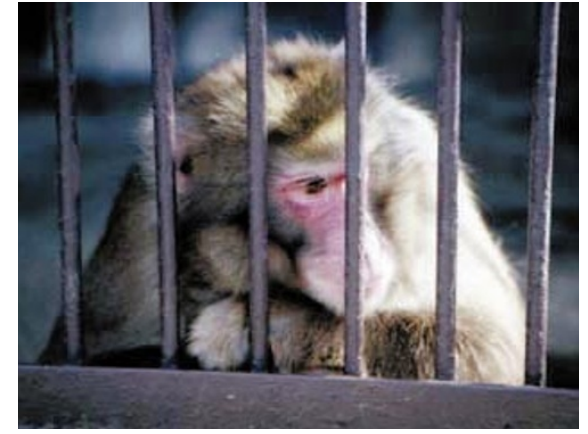

Twist of fate: the sale of Japanese macaques has provoked protests from animal activists.

According to the report, the demand for research monkeys has increased by 100 per cent in ten years, and most scientists are dependent on animals obtained from the wild. Although some national institutes, such as Kyoto University's Primate Research Institute, breed several hundred monkeys each year, external researchers do not have access to such animals.

The shortage of monkeys is partly the result of a decision made eight years ago by Japanese airlines to stop importing monkeys from Africa and South-East Asia to prevent the entry of the Ebola virus (see Nature 382, $744 ; 1996)$. Restricted supply has caused the price of monkeys to increase, and many scientists have been forced to use different species of monkeys.

AsakoSaegusa

\title{
Lawsuit demands labels for modified foods
}

[WASHINGTON] A group of US consumer advocates and scientists is suing the Food and Drug Administration (FDA) for failing to require manufacturers to label genetically modified foods as such, and for what they see as shortcomings in the regulation of their safety.

In a suit filed at the US District Court in Washington DC last week, lawyers at the International Center for Technology Assessment (ICTA) claim that the FDA is violating the Federal Food Drug and Cosmetic Act by failing to require the labelling of the foods, which are now being widely grown and eaten in the United States.

The lawsuit also argues that the FDA should be treating genetic modifications as new food additives, which need to be tested for safety and approved before being sold.

The FDA says that it is not required to label genetically modified foods because they are not materially different from existing foodstuffs. "If the food is different, we require labelling," says Eric Flamm, a policy analyst at the agency. "If it isn't different, we do not."

The agency's biotechnology policy, published in 1992, states that genetic modifications are not regarded as new additives for regulatory purposes, provided they use genes taken from items that are already in the food chain. The lawsuit claims that the agency should be treating all genetic modifications as additives. It challenges what it calls the FDA's failure to label or to regulate 36 genetically altered foods, including corn and tomatoes.

"By failing to require labelling, the FDA has made millions of Americans into guinea pigs for genetically engineered foods," says Andrew Kimbrell, an ICTA lawyer.

The plaintiffs include Philip Regal, professor of ecology at the University of Minnesota, who claims that the FDA is too close to the industries it is supposed to regulate. Regal says that safety risks from genetically engineered foods are " $\mathrm{a}$ scientific certainty".

Colin Macilwain

\section{France seeks the return of the roving scholar}

[PARIS] Lionel Jospin, the French prime minister, last week urged the creation of "a university without walls" in Europe, similar to that which allowed the free flow of intellectuals in Europe during the Renaissance.

Jospin was speaking at the end of a twoday colloquium held at the Sorbonne in Paris, marking the 800th anniversary of the founding of the University of Paris though the date is contested by some. He said the goal should be "for a student to be able to start his studies in Paris, and follow them at Heidelberg, Oxford or Bologna”. He added: "If the rules get in the way of that mobility, then we need to change the rules."

At the end of the meeting, education ministers from the United Kingdom, France, Germany and Italy signed a declaration committing themselves to building a common European university system. This would include harmonizing course structures and encouraging greater mobility of students and staff among European countries.

Jospin, himself a former minister of education, said that a new political impetus was needed. He endorsed the declaration's statement that "Europe is not only that of the Euro, of the banks and the economy; it must be a Europe of knowledge as well".

The four ministers - Claude Allègre (France), Tessa Blackstone (United Kingdom), Jürgen Rüttgers (Germany) and Luigi Berlinguer (Italy) - committed themselves at the meeting to harmonizing their university degree systems. They agreed that this should cover a first degree, a short masters and a longer doctorate degree, including a system for transferring credits obtained for modules and semesters in various European institutions.

This year, around 200,000 students and 31,000 lecturers will take part in the European Commission's exchange schemes such as Socrates and Leonardo. But this is a fraction of the continent's 11 million students.

Discouraging factors include excessive bureaucracy and the relatively low value of grants within the schemes compared with the costs of living abroad. But the lack of mutual recognition of course credits is generally seen as an even larger obstacle.

The ministers backed credit transfer schemes, such as the commission's recently launched European Credit Transfer System, to which around 1,300 universities have signed up.

But the consensus at the meeting was that a new political effort was needed, in particular to take advantage of the opportunities offered by new technologies such as videoconferencing.

DeclanButler 